DOI: $10.15503 /$ jecs20112-124-132

\title{
BETWEEN VANGUARD AND EXCLUSION - YOUNG PEOPLE OF THE TWENTY-FIRST CENTURY
}

\author{
AgNiesZKa GiL \\ aga_gil@wp.pl
}

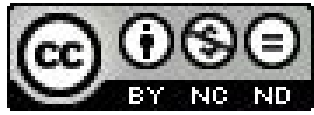

\begin{abstract}
This study has been narrowed down to reveal a paradox. Here the vanguard of culture and civilization - which is regarded as young people of the twenty-first century - is embroiled in a discourse of exclusion: economic, political and cultural life. In secondary school programs and high schools we do not find specific references and studies, primarily based on the needs of students, about the theory of popular culture and cultural education in the area of pop culture. The paradox of exclusion of mainstream culture from educational discourse is schizophrenic. The political exclusion of young people of the XXI century I consider all the disparaging scientific discourse, which skips the actual media and communication competence of young people. Prosumers, cognitarchy, digital natives, C-generation - they are for the modern economy "Silicon Valley" - their market power to exclude is already unstoppable. In other areas it remains to be considered whether excluding young people from the cultural discourse will not deprive our future teachers and translators of the next civilization revolution of social reality...
\end{abstract}

Key words: cultural, economic and political exclusion, popculture, prosumers, cognitarchy, digital natives, C-generation.

Most mentioned conditions in the literature of social exclusion are economic, political and cultural inabilities to participate in social life (see: Krawczyk-Blicharska, Nowak 2010). Writing about the young people of the twenty-first century, we could discuss each of these issues because, as Antonina Kłoskowska accurately notes: "youth is the period during which the individual life history intersects with History" (Kłoskowska 1987, p. 132). However, this study has been narrowed down to reveal a paradox. Here, the vanguard of culture and civilization - which is regarded as young people of the twenty-first century - is embroiled in a discourse of exclusion: economic, political and cultural life. Advocates of critical theory would probably write about empowerment, the excitation of political forces opposing the hidden program of education, politics or economics which are included below are a few observations. Writing about these issues in terms of exclusion it is difficult not to succumb to the that temptation, albeit in relation to youth and the inevitable changes of civilization, after all, let me rather at a distance try to signal a social phenomenon, which is coming to attention in a predominantly Polish humanist discourse (mainly teachers) who write about the young of the twenty-first century. 


\section{CULTURAL EXCLUSION AND SOCIALIZATION IN POP CULTURE}

Youth is the period of formation of the moral powers, to ask the first questions about the meaning of existence and the struggle for the autonomy of one's own philosophy. This intellectual - emotional ferment is the soil out of which society attempts to "sow" seeds of ideas, norms, rules and principles of coexistence. "Socialization is a process through which the individual becomes a fully-fledged member of the social collectivity. At the most general level is to gain these competencies and skills that are necessary for social existence, and therefore of life among others, in cooperation with others. It is a kind of cultural minimum required of all men" (Sztompka 2003, p. 393). It should be emphasized that among the many schools the concept of cultural education (learning about the shaping of human spirituality) in Poland, the most often, chosen position is the deprecation of popular culture and participation in it is treated as a dehumanizing practice. In view of the mainstream opposition, there are also an increasing number of calls to start a dialogue in the field of popular culture (see: Jakubowski 2001, 2002, 2005, 2006a, 2006b, 2008). The "taming" of pop culture, writes Wojciech J. Burszta as "acceptance into the consciousness of the world, without offending that deviates from the ideas and our knowledge of the erstwhile cultural canon, the ideal of an educated man" (Burszta 2002, p. 7). How many contemporary scholars of culture recognize that "since any form of criticism of popular culture on the part of intellectuals and scholars / humanists are doomed to failure and do not affect the subsequent rate of spread of new phenomena from the circle of »low culture «, you may want to make the effort to understand this phenomenon from the perspective of knowledge about culture in a broad sense"(Burszta 2002, p. 7).

The phenomenon of socialization of young people in popular culture enhances the "self-exclusion policy" of teachers, parents and education theorists who, believes Zbyszko Melosik "deprive themselves of influence, do not attempt discussion with young people on terms that are acceptable for her" (Melosik 2004, p. 69). The identity of today's teenage struggle illustrates the forces and social processes: the consumption setting out the way of life, the primacy of immediacy (fast food, fast sex, fast car, the reality in a nutshell, the mobile control over time, space and other people), temporariness, superficiality, changeability, ecstasy escort interactivity, the triumphal procession everyday desacralizing great ideals, banality, triviality, ideology, pleasure, micro-narrative in "procession to the front" (a pragmatic conception of truth), commercialized freedoms, disguised and fragmentation of reality, the cult of body and sexual well-being, mediatization intimacy and privacy, Americanization, globalization, instability and ambivalence, but what is most important, success above all else. When man's identity is a response to the external and internal world, where identity and separateness exist at the same time, when the end is a constitutive challenge of pedagogy, in particular the theory of education and cultural education, not to mention the conditions under which young people came to consciously construct. When analyzing Z. Melosik considerations it is concluded finally due to practical life of teenagers, as a strategy towards the suitability requirements of the reality, the "global teenager" is 
very pragmatic, an easy communicator. A maximum tolerance for difference and diversity (and all the paradoxes), while it is characterized by strong skepticism about the idea of greater involvement - deeper participation (no intention to make any kind of rebellion, to change the world in the name of whatever understood alternatives). However, the teacher is wrong, because - what he perceives - is a symptom of the shallowness, the culture of non-linear, of the moment the culture is, perhaps, the cultural condition for success. If there is an inevitable need for constant adaptation to the invasive and chaotic change, the need to "jump" from one to the other forms of manifestation of instant culture, to live in a culture full of contradictions, a culture that does not give clear answers, in which anything can happen, it is perhaps that the lack of commitment (or more radical: the lack of core identity) is a prerequisite for cultural survival" (Melosik 2004, p. 85).

Meanwhile, in secondary school programs and high schools we do not find specific references and studies, primarily based on the needs of students, about the theory of popular culture and cultural education in the area of pop culture. The paradox of exclusion of mainstream culture from educational discourse, as rightly observed by Witold Jakubowski, is schizophrenic.

\section{POLITICAL EXCLUSION IN CIVILIZATION OF MEDIA}

Without going into discussion about what is and is not a policy, for the purposes of this paper, we assume that it is power and the fight for it, but also the result of ideology, tradition and aspirations. Political action is on the level of the whole society (including international interests). Nowadays, the place of shaping and demonstration of political power is the media.

Institutionally empowerment to contribute to the development of competence in media discourse takes place within the framework of media education. Education is the teaching of language and social rules of communication, when the means of mass communication does not look like the technical instruments, but the social institutions that bring together both the technical means of production and distribution of transfers, as well as teams of developers to prepare these messages. Tomasz Goban-Klas suggests that in contrast to the technical instruments to call them means of social communication, "intermediary" between the world (reality) and the public. Social communication mediated by the media is not homogeneous. It is distinguished by four main types of media: mass, popular, elite and alternative (dissenting). In each, however, can be seen, more or less realized by customers, the process of creating, distributing and receiving orders, with corresponding ideology subordinate to the rules of social organization (power sharing). Media largely makes (creates) social reality, establishes standards of behavior, norms, models, etc. Media (media organizations) are manufacturers and distributors of knowledge in the broadest sense of the word. This knowledge enables people to orientate in the world, and for many is the main source of information about past and present. According to T. Goban-Klas, "in modern secular society dependence is on the media as it once was from the church, school, peers, parents" (GobanKlas 2001, p. 110-114). 
On the other hand, analyzing the relationship a child / TV, J. Ziemek concludes: "Sociologists say that under the influence of associating with the transfer of audiovisual and multimedia in teenagers is as »third-wave mentality«. One notable feature of this mentality is pro-technological slant, focusing solely on hedonistic consumption and non-reflective media communications that are available on the market. This means breaking the danger of contact with reality and the closure of the world in a particular substitute: video games, television programs (such as MTV or favorite films) as self-contained worlds" (Ziemek 1997, p. 5). Many educators share these concerns, so it seems an understandable definition of media literacy is "the development of competence in using the language of the media, as an introduction to the cultural media in order to prepare children for a critical, active, selective collection and create their own programs" (Izdebska 2001, p. 113).

Also pay attention to the study of Hanna Tomaszewska, the communication of young people in the era of social media, invested with modern theories of mass communication, describing, among others phenomena mediated communication, social media, world saturated (supersaturated) with media, mediatization (see: Goban-Klas, 2005), the digital divide and the generational digital divide. The author widely describes a phenomenon mentioned as the last - the generational digital divide, which may arise from the manner in which the media are constructed (see: Goban-Klas, Sienkiewicz 1999, p. 43). He writes: “They are in fact created by young people for young people and also young people, as research indicates, are the most frequent users (see: Batorski 2003, 2005, 2007, Wenzel 2006, 2007, 2008). (...) dynamics, movement, color, lack of linearity, multithreading, iconity are adapted to the perception of the generation brought up on the image. Youth and children intuitively learn to use new equipment, while their parents in the acquisition of competence in media have clear difficulties (see: Holloway, Valentine, 2003, p. 72-82). (...) This phenomenon Zbigniew Kwieciński describes as a "shift of socialization" of the traditional socialization, instance "top down" - family and school - the peer group and media (see: Kwiecinski 1999)" (Tomaszewska 2009, p. 194). H. Tomaszewska writes about important observations on the relationship of young people in "face to face" and media communication. As noted: "Often, from the perspective of teens just »being always available « (always online) - thanks to constantly activated cell phone or communicator - turns out to be more important than the exchange of communications in general will, and what will be affected. New media in the opinion of high school students works well when you need to transfer specific information - such as arranging a transfer, what is the answer or what to bring to school, eventually reported to what happened during the day. Youth, however, is often referred to when communicating through the media as an artificial, false, unreal - as opposed to real, authentic and that real, occurs only when we meet with another person. (...) Contacts with new media, is easier to maintain but not to increase or strengthen. »There is no bond by the media « - some teenagers are explicit. The real and deep relationship with another person, in the opinion of the vast majority can only be built by communicating »face to face «" (Tomaszewska 2009, p. 199). 
In one of the many interviews Marc Prensky ${ }^{1}$ notes, "For me - and I am 65 years old - technology always remains an artificial, external phenomenon. Yes, I use it so that I can, I use it and like it. But technology does not breathe. For digital natives - a generation that does not know the world before the Internet - technology is not just a tool. This reality is also internal (...) We - »digital emigrants « - we are "people«, they are »people-to-machine«. Maybe they have some problems with the fact that these machines are overwhelming them, taking control of their lives. But for this more than the older generation accustomed to cooperation. They can and they like not only to use and transfer cultural goods, but also combine them with themselves change, enrich. »Digital natives « have a problem with authorities. That's because they gain knowledge about the world and its governing laws. Instead of being limited to what the media tells them, twitting with the U.S. President, with people occupying Wall Street... "(Pezda 2011).

The paradoxical adolescent mind of the "third wave" - twitting with the U.S. President and is lost in hedonistic media transmission of unreality... These maybe are two different teenagers? American and Pole. This may be simultaneous influence of the media? The U.S. President is the same as The Witcher (Wiedźmin). Or maybe a teenager knows how to navigate the media world? What is worth discussion on the global forum, will discuss what is silly and dangerous, laugh with friends, or send a warning...

The political exclusion of young people of the XXI century I consider all the disparaging scientific discourse, which skips the actual media and communication competence of young people. Certainly young people do not operate categories, which formed our social world but they are creating categories, which the architects of the new world will operate.

In this area, Tadeusz Miczka also invests his reflections on education in the hypermedia, "informative revolution produces educational revolution, involving the decentralization of education, acceptance of a number of alternative models of education adapted to the needs and interests of social groups and individuals, as well as the integration of education and entrepreneurship and skills called for in the elaboration of professional flexibility. (...) Particularly important is the extent of media education, it is precisely because it is evidence of its specific nature and location in fundaments of education. It is almost certain that media education will form the basis of all the processes of teaching and education, because all the previous items, programs, types and fields of activities are increasingly linked with the techniques of information and their development increasingly depends on the media"(Miczka 2004, p. 13). This statement clearly shows the dramatic situation of formal learning / teaching, which is forced into a "catch up" level of education mediatized non- and out - formal, in which areas, in addition to communication practices, and (pop) culture, we find areas of influence in all areas of social functioning - including, despite all, local circumstances (such as the information gap). "Hipertextual nature of media education - continues T. Miczka - of course,

The most important author's works: Digital game-based learning, New York 2001; Don't bother me mom - I'm learning, St. Paul 2006; Teaching digital natives, Thousand Oaks 2010; planed to be edited in 2012: From digital natives to digital wisdom. 
includes not only the essence of the phenomena of information, but also the user's communicative competence in the modern media, an active participant in the culture and cultural manager. (...) As for education, it does not respect many of the existing principles of pedagogy, because it acquires its meaning and its 'reality' in the form of a non-ending, non-final, and even un-sure "(Miczka 2004, p. 14).

The author attempts to determine the conditions necessary for the efficiency and effectiveness of teaching media education. Proposes to treat it as an alternative form of pedagogy, but understood "in peace", that is not antagonistic and competitive to other subjects and pedagogy, but still adjusting to reality, taking into account the mobility of the information society. It should assign less importance to epistemological knowledge (doubling every year, even every few months). Instead, consider the objective of developing skills that are associated with cognitive knowledge, which rely on the use of a variable state of knowledge.

This approach to the problem refers to the demands, formulated by Gregory Bateson (1973). The researcher distinguishes:

- primary learning - highly ideological and controlled,

- learning to learn - learning of the second degree, which in the second half of the twentieth century, under the influence of intensive innovation and social development, increasingly displaced the first type. Consists of decreasing the involvement of knowledge about materials and the canon, and focused attention on the rapid learning of what in a given society is considered useful,

- learning skills in a rapid orienting towards inadequacy or uselessness of knowledge, and held on stress patterns in the organization of a new meaningful whole - learning of the third degree, in the era of before - and informative society.

According to Zygmunt Bauman, this is just an art of the orientation inadequacy and flexibility of the organization that today's pedagogy must conquer. As he notes: "It's not about devaluation of learning, but about change of the traditional concepts of learning and the need to develop new strategies, which yet we do not have" (Zeidler-Janiszewska 1997, p.55).

About the necessity for a new strategy, the irreversible consequence of the use or omission speaks T. Miczka: "Regardless of what the future of computers, media education must be based on the distance to the current techniques, developments and trends, must kindle the imagination, to see new horizons of high technology and reform curricula and education. In other words, developers and media education participants should - avoiding the final settlement - for example, issues include the possible crowding out of school education through distance education replacing traditional schools and universities with new educational institutions, such as networking agencies and virtual education institutions, which will have available virtually unlimited range of educational and the most democratic structures and control the exchange of knowledge. (...) One of the most important consequences of the media revolution, which is a very important mechanism shaping the information society is the decisive role of knowledge and skills in development, every person, every society and the global community, which gains that knowledge is 
simply investing in education. Every state, every culture and every society that neglects this kind of investment, is condemned to be distanced from this situation, the situation on the side of people being programmed, rather than programming. Propulsion of the information society is the new class, mostly called cognitarchy, who professionally deal with the collection, production, remodeling and dissemination of information, which is the "new knowledge«" (Miczka 2004, p. 19).

\section{ECONOMIC EXCLUSION?}

In the context of young people of the twenty-first century, as a cultural and civilizational vanguard, also deserving attention are phenomena such as culture of constituent participation, generation of her creators - the prosumers ${ }^{2}$ and C-generation: "As the population prosumers are part of the so-called C-generation a group of consumers, which in contrast to other generations $(X, Y$, baby boomers, etc.) is not defined demographically and behaviorally. C-generation is a group that is characterized by the desire to have influence and control and higher than average - creativity, communication and the number of contacts with others (connection). Consumers who are part of C-generation are contemporary artists: create, comment, exchange ideas. This trend is particularly noticeable on the Internet - the C-generation is responsible for the success of sites such as YouTube (making one's own movie material and showing it to millions of people around the world), or our-class.pl based on strong efforts of people to create social networks" (Hatalska 2011). Along with the culture of participation, arise such burning issues as: copyright and culture (YouTube, "wrzuta", creative commons), convergence culture $^{3}$ - the media push / pull media, the gap of access / participation gap, culture 3.0, media literacy (Marschall McLuhan), electronic democracy (Browning 1997). Among the recipients of contemporary culture, people are also referred to as adulescent (Anatrella 2003, p. 37-47). It is a term which is a conglomeration of two words: adult and adolescent (teenager) to denote a person middle-aged remaining participants of youth culture and its English equivalent - kidult (Berlińska 2011).

Prosumers, cognitarchy, digital natives, C-generation - they are for modern economy "Silicon Valley", the salt of the earth - their market power to exclude is already impressive. In other areas it remains to be considered whether excluding young people from the cultural discourse and not paying them a sense of well-

2 As the first Alvin Toffler introduces the concept of prosumer as a creative consumer who develops for itself a commodity. The author notes that the first farmers were prosumers (first wave), but the industrial revolution to separate production from consumption, and "merchandising" life, made them consumers, while depreciating the production for personal use (second wave). Only the shaped market and mental transformation in social sphere (self-service) allow, in the opinion of the author, to return to their own scale production of consumer needs (third wave) (Toffler 1984, p. 309 - 333).

3 In a culture of convergence, „fans are the elite in developing digital media culture environment actively convert the official texts of culture, create remixes and own productions inspired by pop culture. Their creativity, formerly operating on the margins of culture, thanks to the powerful and free channels more often translates to co-operate and sometimes even compete with commercial producers". Mirosław Filiciak words in a conversation with Henry Jenkins (Jenkins 2010, p. 136). 
deserved recognition for the competences acquired after sleepless nights in front of a computer screen and to be vigilant always-in-network, do not deprive our future teachers and translators of the next civilization revolution of social reality...

\section{BIBLIOGRAPHY}

Anatrella T. (2003), Les Adulescents, „Revue Etudes” 7 (399).

Bateson G. (1973), Steps to an Ecology of Mind, Paladin, St. Albans.

Batorski D. (2003), Ku społeczeństwu informacyjnemu [in:] Czapiński J., Panek T. (eds.), Diagnoza Spoteczna 2003. Warunki i jakość życia Polaków, WSFiZ, Warszawa.

Batorski D. (2005), Społeczne aspekty korzystania z nowych technologii [in:] Czapiński J., Panek T. (eds.), Diagnoza Społeczna 2003. Warunki i jakość życia Polaków, WSFiZ, Warszawa.

Batorski D. (2007), Uwarunkowani i konsekwencje korzystania z technologii informacyjno-komunikacyjnych [in:] Czapiński J., Panek T. (eds.), Diagnoza Społeczna 2003. Warunki i jakość życia Polaków, WSFiZ, Warszawa.

Borkowski I. (ed.) (2004), Edukacja medialna. Teksty i preteksty, Oficyna Wydawnicza Arboretum, Wrocław.

Browning G. (1997), Elektroniczna demokracja, MIKOM, Warszawa.

Burszta W. J. (2002), Edukacja popkulturowa? [in:] Burszta W. J., de Tchorzewski A. (eds.), Edukacja w czasach popkultury, Wydawnictwo Akademii Bydgoskiej, Bydgoszcz.

Burszta W. J., de Tchorzewski A. (eds.) (2002), Edukacja w czasach popkultury, Akademia Bydgoska, Bydgoszcz.

Czapiński J, T. Panek (eds.) (2003), Diagnoza Społeczna 2003. Warunki i jakość życia Polaków, WSFiZ, Warszawa.

Gnitecki J., Rutkowiak J. (eds.) (1999), Pedagogika i edukacja wobec nadziei i zagrożeń wspótczesności: materiaty z III Ogólnopolskiego Zjazdu Pedagogicznego, Polskie Towarzystwo Pedagogiczne, Warszawa-Poznań.

Goban-Klas T., Sienkiewicz P. (eds.) (1999), Społeczeństwo informacyjne: szanse, zagrożenia, wyzwania, Wydawnictwo Fundacji Postępu Telekomunikacji, Kraków.

Goban-Klas T. (2001), Media i komunikowanie masowe. Teorie i analizy prasy, radia, telewizji i Internetu, PWN, Warszawa - Kraków.

Goban-Klas T. (2005), Cywilizacja medialna, WSiP, Warszawa.

Holloway S.L., Valentine G. (2003), Cyberkids. Children in the Information Age, RoutledgeFalmer, London.

Izdebska J. (2001), Sceny przemocy w telewizji a zachowania dzieci - uwarunkowania oraz konieczność dziatań pedagogicznych [in:] Żebrowski J. (ed.), Zjawiska patologii społecznej i zachowań dewiacyjnych młodzieży, Gdańskie towarzystwo naukowe, Gdańsk.

Jakubowska-Malicka L., Kobylarek A., Pryszmont-Ciesielska M. (eds.) (2009), Ponowoczesne konteksty edukacji. Audiowizualność - Cyberprzestrzeń - Hipertekstualność, Oficyna Wydawnicza Atut, Wrocław.

Jakubowski W. (2001), Edukacja i kultura popularna, Impuls, Kraków.

Jakubowski W. (2002), Edukacyjne konteksty kultury popularnej, Impuls, Kraków.

Jakubowski W. (2005), Media, kultura popularna, edukacja, Impuls, Kraków.

Jakubowski W. (2006a), Edukacja w świecie kultury popularnej, Impuls, Kraków.

Jakubowski W. (ed.) (2006b), „Dzisiejsze czasy" - edukacja wobec przemian w kulturze wspótczesnej, Impuls, Kraków.

Jakubowski W. (ed.) (2008), Kultura i edukacja (konteksty i kontrowersje), Impuls, Kraków.

Jenkins H. (2007), Kultura konwergencji. Zderzenie starych i nowych światów, Wydawnictwo Akademickie i Profesjonalne, Warszawa.

Jenkins H. (2010), Nowe formy uczestnictwa w kulturze [in:] Filiciak, M. Danielewicz, M. Halawa M., Mazurek P., Nowotny A. (eds.), Młodzi i media. Nowe media a uczestnictwo w kulturze. Raport centrum badań nad kultura popularna SWPS, Szkoła Wyższa Psychologii Społecznej, Warszawa.

Kłoskowska A. (1987), Socjologia młodzieży: przeglad koncepcji, „Kultura i Społeczeństwo” 2.

Krawczyk-Blicharska M., Nowak P. (2010), Poradnictwo społeczno-zawodowe forma przeciwdziałania wykluczeniu społecznemu [in:] Piorunek M. (ed.) Pomoc - wsparcie społeczne - poradnictwo. Od teorii do praktyki, Adam Marszałek, Torun. 
Kwieciński Z. (1999), Edukacja wobec nadziei i zagrożeń wspótczesności [in:] Gnitecki, J. Rutkowiak J., (eds.) Pedagogika i edukacja wobec nadziei i zagrożeń wspótczesności: materiaty z III Ogólnopolskiego Zjazdu Pedagogicznego, Polskie Towarzystwo Pedagogiczne, Warszawa-Poznan.

Kwieciński Z., Śliwerski B. (eds.) (2004), Pedagogika, PWN, Warszawa.

Melosik Z. (2004), Kultura popularna jako czynnik socjalizacji [in:], Kwieciński Z., Śliwerski B., (eds.), Pedagogika, PWN, Warszawa.

Miczka T. (2004), Edukacja medialna jako podstawa ksztatcenia i wychowania w społeczeństwie informacyjnym [in:] Borkowski I. (ed.) (2004), Edukacja medialna. Teksty i preteksty, Oficyna wydawnicza Arboretum, Wrocław.

Pezda A. (2011), Dyktatura nastolatkóww? Czemu nie?! (rozmowa z Markiem Prenskym), „Gazeta Wyborcza", 10-11.12.

Piorunek M. (ed.) (2010), Pomoc - wsparcie spoteczne - poradnictwo. Od teorii do praktyki, Wydawnictwo Adam Marszałek, Torun.

Sztompka P. (2003), Socjologia, Znak, Kraków.

Toffler A. (1984), Trzecia fala, PIW, Warszawa.

Tomaszewska T. (2009), Komunikacja młodzieży w dobie społeczeństwa medialnego jako wyzwanie dla więzi międzypokoleniowych [in:] Jakubowska-Malicka L., Kobylarek A., Pryszmont-Ciesielska M. (eds.) (2009), Ponowoczesne konteksty edukacji. Audiowizualność - Cyberprzestrzeń - Hipertekstualność, Oficyna Wydawnicza Atut, Wrocław.

Zeidler - Janiszewska A. (ed.) (1997), O szansach i putapkach nowoczesnego świata. Materiaty z seminarium Profesora Zygmunta Baumana w Instytucie Kultury (jesień 1995 - wiosna 1996), Instytut Kultury, Warszawa.

Ziemek J. (1997), Joystickowe manipulacje, „Tygodnik Powszechny” 28.

Żebrowski J. (ed.) (2001), Zjawiska patologii społecznej i zachowań dewiacyjnych młodzieży, Gdańskie towarzystwo Naukowe, Gdańsk.

\section{NETOGRAPHY}

Berlińska A. (2011), Kidult w średnim wieku, http://www.rp.pl/artykul/9132,67388_Kidult_w_srednim_wieku.html, retrieved: 02.09.2011.

Hatalska N. (2011), Prosumer, http:/ / hatalska.com/slownik/prosumer, retrieved: 01.09.2011.

Wenzel M. (2006), Internet $i$ komputery: wyposażenie gospodarstw domowych, sposoby $i$ cele korzystania, Komunikat CBOS BS/58/2006, Warszawa, http://www.cbos.pl/SPISKOM.POL/2006/K_058_06. PDF, retrieved: 23.08.2011;

Wenzel M. (2007), Korzystanie z Internetu i komputerów, Komunikat CBOS BS/59/2007, Warszawa, http://www.cbos.pl/SPISKOM.POL/2007/K_059_07.PDF, retrieved: 23.08.2011;

Wenzel M. (2008), Polacy w sieci, Komunikat CBOS BS/58/2008, Warszawa, http://www.cbos.pl/SPISKOM.POL/2008/K_058_08.PDF, retrieved: 23.08.2011. 